\title{
EFFECT OF RUMEN-PROTECTED CHOLINE SUPPLEMENTATION ON PRODUCTIVE PERFORMANCE OF LACTATING DAIRY COWS
}

\section{M.H. Bakr ${ }^{1 *}$ and Sherein H. Mohamed ${ }^{2}$}

1-Department of Animal Production, Faculty of Agriculture, Cairo University, 2- Department of Animal Production, Faculty of Agriculture, Banha University*Corresponding author: (mhmbakr@agr.cu.edu.eg)

\author{
Received: 1/9/2019 Accepted: 16/10/2019
}

SUMMARY

Nine Holstein lactating cows, with an average live body weight of $550 \pm 50 \mathrm{~kg}$, at $1^{\text {st }}$ to $3^{\text {rd }}$ seasons of lactation, were selected and randomly assigned to three similar groups (three cows each). Cows were used in a lactation study for a total of 12 weeks (4-week prepartum to 8-weeks postpartum) to investigate the effect of feeding two levels of rumen protected choline (RPC) supplementation, at 40 or 50 grams RPC/cow /day, or with no supplement (control) on compare milk production parameters and performance of dairy cows.Results showed insignificant differences ( $P>0.05)$ among groups in the digestibility coefficients of DM, OM, CF,EE and NFE, and also in nutritive value as TDN \%, while CP digestibility coefficient and nutritive value as DCP\% in $R P C$ groups were significantly $(P<0.05)$ higher than the control group. The milk yield of treated groups with 40 and $50 \mathrm{gm}$ of RPC were higher than control(11.39\% and 22.62\%) and fat corrected milk (4\%) at 10.88\% and $21.45 \%$ higher than the control group. Insignificant $(P>0.05)$ differences were observed between the groups in their average daily $D M$ and TDN intake, while results of DCP intake were significantly $(P<0.05)$ higher in favor of groups fed both levels of RPC. The treated group with $50 \mathrm{gm} R P C$ was significantly $(P<0.05)$ better than control for feed conversion, DM, TDN and DCP. No significant differences $(P>0.05)$ were observed in change of body weight through the experimental period among all the three groups. However RPC groups showed numerically lower weight losses compared to the control. Insignificant differences were found among the groups in the content of milk protein, fat, SNF, TS and lactose. No significant differences were noted between the groups in AST, ALT and cholesterol contents, while RPC groups recorded significant $(P<0.05)$ low values of triglycerides and $L D L$ and significantly $(P<0.05)$ higher values of $H D L$ compared with the control. The groups of 50 and $40 \mathrm{gm} R P C$ recoded lower feed cost for production of $1 \mathrm{~kg}$ milk being 3.17, 3.47compared to control at $3.77 \mathrm{LE}$, and increase in the daily net milk revenue being 58.76, 47.76, compared to control at $37.78 \mathrm{LE}$, and economic feed efficiency being $89.3 \%$, $73.0 \%$ for the control at $59.2 \%$. Relative economic efficiency were $156 \%, 126.4 \%$ and 100\% compared with the control group, respectively. The obtained results indicated that RPC supplementation at 40 or $50 \mathrm{~g} /$ head/day could improve digestibility, milk yield and composition, feed conversion, and economic efficiency in lactating Holstein cows. More researches are needed with higher number of dairy animal.

\section{Keywords: Rumen, feed conversion, economic efficiency, protected choline, milk yield}

\section{INTRODUCTION}

The NRC (2001) establishment of choline requirements for lactating dairy cow and transitional cow in the late dry period and in early lactation, requires more extensive feeding experiments than currently available in the scientific literature to date 2016. Choline is sometimes classified as a B vitamin; even though it does not fulfill the standard definition of vitamins, it is an essential nutrient when excess amounts of methionine and folate are not available (NRC 2001). Choline is a tri-methylated quaternary amine involved in metabolism and transport of fat from the liver. It provides labile- methyl groups for trans-methylation reactions and is required for the synthesis of phosphatidyl choline found in cell membranes (Hartwell et al, 2000; Zahra et al., 2006). It has the ability to increase milk fat synthesis (Erdman et al., 1984) and to treat cows suffering from fatty livers after parturition (Cooke et al., 2007). However, extensive degradation of unprotected dietary choline by rumen bacteria require the use of rumen-protected supplements containing choline chloride, which is subsequently released and absorbed as choline in the small intestine (Atkins et al., 1988; Erdman and Sharma, 1991;Deuchler et al., 1998;Pinottiet al., 2003; Cooke et al., 2007; Zom et al., 2011).

The elevated fat in the liver is associated with poor reproductive performance (Bobe et al., 2004). When feeding transition cows RPC, the reduction in liver fat content occurs and is accompanied by improvement in health and production. Feeding lactating cows RPC from 25 days pre-partum to 80 days post-partum resulted in reduced incidences of clinical ketosis, mastitis, and morbidity (Lima et al, 2011). According to Bobe et al. (2004), 50 to $60 \%$ of transitional cows - in several studies- have shown experience moderate to severe fatty liver. At birth, concentrations of non-esterified fatty acids (NEFA) usually increase from 5 to 10 times which is a result of the hormonal changes leading to an intense period of fat mobilization of fat tissue during this critical time (Grummer, 1993). The NEFA remain elevated, although to a lesser extent, during early lactation when cows experience negative energy balance. Blood flow to the liver doubles as a cow experience transition from the dry period to lactation (Reynolds et al., 2003). The NEFA concentration and blood 
flow are the two main factors affecting how much NEFA is taken up by the liver. Consequently, daily fatty acid uptake by the liver increases 13-fold at calving, from approximately 100 to $1300 \mathrm{~g} /$ day (Reynolds et al., 2003).

It is now clear that choline deficiency is a limiting factor for very low density lipoprotein (VLDL) triglyceride export from the liver. The rate of VLDL export is highly related to the rate of hepatic choline synthesis which has been shown in many species; using a wide variety of experimental approaches (Cole et al., 2011). For the effect of addition RPC on milk yield and composition of dairy cows, $\mathrm{Xu}$., et al (2006) reported that, addition RPC by dose of $25 \mathrm{~g} / \mathrm{d}$ to dairy cows resulted in increasing milk production by $0.92 \mathrm{~kg}$ and $0.82 \mathrm{~kg}$ more than that of the control group, with little difference in contents of milk fat and milk protein. Also, Mohsen, et al (2011) reported that RPC supplementation at $30 \mathrm{~g} /$ head/day to lactating Friesian cows improved digestibility, milk yield and composition, feed conversion, and economic efficiency.

The objective of this study is to evaluate the effect of RPC supplementation at 40 and 50 $\mathrm{g} /$ head/day to lactating Holstein cows on digestibility, milk yield and composition, blood constituents, feed conversion and economic efficiency.

\section{MATERIALS AND METHODS}

The experimental work of this research was conducted at the dairy farm, Agricultural Experiments Station, Faculty of Agriculture, Cairo University. Milk analyses were conducted at Cattle Information System/Egypt (CISE) and blood samples were analyzed at laboratories of Hormones, at Faculty of Agriculture Research Park (FARP). The chemical analyses of feeds, feces, were conducted at laboratories of Regional Center for Food and Feed, Agriculture Research Centre, Ministry of Agriculture, Egypt.

Nine Holstein lactating cows, in their first to third season of lactation, and one month prenatal were randomly allotted to three matched experimental groups. First group served as a control, while the second and third groups were supplemented with two levels of RPC, 40 and $50 \mathrm{gm} /$ day/cow, respectively. The RPC supplementation beganduring last month of transitional period and 2 months postpartum. Rations were weighed for each group two times a day, at 7 AM and 7 PM. The quantities of daily feed /day/cow were (on average) $12 \mathrm{~kg}$ concentrate feed mixture $(\mathrm{CFM})+4 \mathrm{~kg}$ Egyptian clove hay $+3 \mathrm{~kg}$ rice straw. The offered feeds were assessed to cover the nutrient requirements for each dairy cow according to NRC (2001). The concentrate to roughage ratio in all rations was offered at approximately 63: $37 \%$ on DM basis. Drinking water was made available all the time during the day.

Formulation and chemical composition of experimental rations and feed ingredients are shown in Tables (1 and 2). Feed refusals were recorded once daily. Feeding allowances were adjusted every week according to changes in body weight and milk production. Rumen-protected choline (CholineSave $\left.{ }^{\circledR}\right)$ in the form of choline chloride, was produced at PACTA-Italy, and distributed in Egypt by DPA SERVICE Company. The product is consisted of $250 \mathrm{gm}$ choline chloride and $750 \mathrm{gm}$ palm oil and de-gummed, refined and hydrogenated. Dairy cows were machine milked twice a day at 6.00 am and $6.00 \mathrm{pm}$. The milk yield was daily recorded. Fat corrected milk (4\%) was calculated according to the following formula of Gaine (1928): FCM \%= actual milk yield $(\mathrm{kg}) \times 0.4+15 \times$ fat yield $(\mathrm{kg})$. Milk samples were collected from three cows of each dietary treatment, to determine its composition using Milk-Scan (Model 133 B). Blood samples were taken via jugular vein in non-heparinized vacationer tubes from three cows in each dietary treatment just before morning feeding. Blood samples were centrifuged for 15 minutes at 4000 r.p.m to obtain the plasma then stored at $-20{ }^{\circ} \mathrm{C}$ till the time of assay. Aspartic transaminase (AST) and/or alanine transaminase (ALT) were assayed in the plasma as described by Reitman and Frankel (1975). Plasma total cholesterol, high-density lipoprotein(HDL), low-density lipoprotein (LDL)and triglycerides $(\mathrm{mg} / \mathrm{dl})$ were determined using bio-Merieux kits (Mary01, Eliot Charbnniere-Les -Beins, France).

Table 1. Feed formulation of concentrate feed mixture (CFM)

\begin{tabular}{lc}
\hline Ingredients & $\%$ \\
\hline Yellow corn grains & 45 \\
Soybean meal $44 \%$ & 22.5 \\
Sunflower meal 36\% & 7.5 \\
Wheat bran & 20 \\
Limestone & 2.4 \\
Sodium chloride & 1 \\
Vit. \&Min. Mix." & 0.3 \\
Sodium bicarbonate & 0.8 \\
Di calcium phosphate & 0.5 \\
Total (\%) & 100 \\
\hline "Each 3 kg vitamins and minerals mixture contains: Vit A 4800000 IU; Vit D3 1000000 IU; Vit E 28000 mg; Zinc 100000 mg; Manganese \\
80000 mg; Iron 75000 mg; Copper 30000 mg; Iodine 750 mg; Cobalt 200 mg; Silinum 300 mg; Calcium bicarbonate up to 3 kg.
\end{tabular}


Table 2. Chemical analysis of CFM, Egyptian clover hay, rice straw and total mixed ration supplemented with choline on DM basis

\begin{tabular}{|c|c|c|c|c|c|c|c|}
\hline \multirow[t]{2}{*}{ Item } & \multirow[t]{2}{*}{ DM \% } & \multicolumn{6}{|c|}{ Composition \% } \\
\hline & & $\mathbf{O M}$ & $\mathbf{C P}$ & $\mathbf{C F}$ & $\mathbf{E E}$ & NFE & ASH \\
\hline Concentrate feed mixture (CFM) & 93.2 & 92.6 & 18.53 & 6.73 & 4.81 & 62.53 & 7.4 \\
\hline Egyptian clover hay & 91.55 & 88.19 & 14.25 & 27.86 & 2.12 & 43.95 & 11.81 \\
\hline Wheat straw & 90.00 & 81.22 & 4.50 & 33.11 & 1.11 & 43.95 & 18.78 \\
\hline Total Mixed Ration (TMR) & 92.40 & 89.60 & 14.90 & 15.50 & 3.60 & 55.60 & 10.40 \\
\hline
\end{tabular}

Digestibility trails:

At the end of the feeding trial, a digestibility trial was conducted to determine the digestion coefficients and the feeding value of experimental rations by applying Acid Insoluble Ash (A.I.A) technique as a natural internal marker as described by Van Kerulen and Young (1977). Fecal grab samples were taken from the rectum twice daily at 8 am and 8 pmfor 5 days. Feces samples were kept frozen at $-18^{\circ} \mathrm{C}$ for further chemical analysis. Chemical analysis of feeds for both digestibility and feeding trials and feces were carried out according to A.O.A.C (1995). Dry matter digestibility and digestion coefficient were calculated according to the equations of Schneider and Flatt (1975) as follows:

DM digestibility $(\%)=100-[100 *$ AIA $\%$ in feed/ AIA $\%$ in feces]

Digestion coefficient of nutrient $=100-(100 \times$ AIA $\%$ in feeds $\times$ Nutrient in feces) $/$ (AIA $\%$ in feces $\times$ Nutrient $\%$ in feeds).

Statistical analysis:

Analysis of variance (one-way, ANOVA) was performed to compare between different groups. Statistical analysis was carried out using SAS (2003) and Duncan's multiple range test (Duncan, 1955) was used to separate the means when the main effect was significant. The following model was used:

$$
Y_{i j}=\mu+T i+e_{i j}
$$

Where: $Y_{\mathrm{ij}}=$ Individual observation, $\mu=$ overall mean, $T_{i}=$ effect of treatment, $e_{i j}=$ random error.

\section{RESULTS AND DISCUSSION}

Digestibility Coefficients:

Results of digestibility coefficients (Table 3) of $\mathrm{DM}, \mathrm{OM}, \mathrm{EE}, \mathrm{CF}$ and NFE, showed insignificant
$(\mathrm{P}>0.05)$ differences among control and RPC supplemented groups. On the other hand, RPC groups recorded significantly $(\mathrm{P}<0.05)$ higher $\mathrm{CP}$ digestibility compared with the control. Regarding the nutritive value of experimental rations, although no significant differences $(\mathrm{P}>0.05)$ were detected among control and RPC groups in TDN, the 50 and 40 gm RPC groups recorded consistently higher values compared with the control $(74.74,74.33$ and 70.50 respectively). Results of DCP showed that RPC groups were significantly $(\mathrm{P}<0.05)$ higher compared with the control. The results of this study were consistent with those reported earlier by Jayaprakash et al. (2016) who found thatincreasing choline supplements produces more volatile fatty acid (VFA) acetate and rumen $\mathrm{pH}$ tends to increase digestibility coefficient of nutrients in rumen. Also, Mohsen et al. (2011) found significant increase in digestibility coefficient of DM, OM, CP, CF, EE, and NFE. This might be because of RPC enhances the protozoa population in the rumen. El-Gendy et al., (2012) indicated that rumen-protected methionine (RPM) and/or choline additives improved nutrients digestibility and subsequently nutritive values in dairy goats, which is consistent with the results of our findings. Mohsen et al., (2011) also reported that the quadratic analysis showed that RPC supplementation at $30 \mathrm{~g}$ produced the highest TDN $(65.07 \% \mathrm{R} 2=0.71)$ and DCP (9.65\%, R2=0.60). Donkin, (2002) and Pinottiet al. (2002) stated that choline is a quasivitamin that has a variety of functions in mammalian metabolism.

Table 3. Digestion coefficients and nutritive values of the experimental rations (on DM basis)

\begin{tabular}{|c|c|c|c|c|}
\hline \multirow[t]{2}{*}{ Items } & \multicolumn{4}{|c|}{ Experimental rations } \\
\hline & $\mathbf{R}_{1}$ & $\mathbf{R}_{\mathbf{2}}$ & $\mathbf{R}_{\mathbf{3}}$ & $\pm \mathrm{SE}$ \\
\hline \multicolumn{5}{|l|}{ Apparent digestibility, \% } \\
\hline Dry matter & 61.54 & 67.13 & 67.41 & 2.89 \\
\hline Organic matter & 67.79 & 70.88 & 71.38 & 2.57 \\
\hline Crude protein & 73.22 & 83.89 & 83.15 & 1.94 \\
\hline Ether extract & 79.04 & 85.02 & 85.55 & 2.29 \\
\hline Crude fiber & 53.24 & 58.21 & 60.14 & 3.68 \\
\hline $\mathrm{N}$-free extract & 75.89 & 77.90 & 78.42 & 2.08 \\
\hline \multicolumn{5}{|l|}{ Nutritive value, $\%$} \\
\hline Total digestible nutrients (TDN) & 70.50 & 74.33 & 74.74 & 1.42 \\
\hline Digestible crude protein (DCP) & $10.91^{\mathrm{b}}$ & $12.50^{\mathrm{a}}$ & $12.39^{\mathrm{a}}$ & 0.36 \\
\hline
\end{tabular}

a,b,c means on the same row with different super script are significantly $(\mathrm{p}<0.05)$ different 


\section{Milk Yield and Feed Efficiency: \\ Milk Yield:}

Average daily milk yield and fat corrected (4\%) milk (FCM) for the whole experimental period are given in Table 4 . The obtained results revealed that groups supplemented with RPC recorded significantly $(\mathrm{P}<0.05)$ higher yield of both actual and fat corrected milk (4\%) than the control. Ardalan et al. (2010) reported that cows whichreceived $18 \mathrm{~g} / \mathrm{d}$ of RPM, $60 \mathrm{~g} / \mathrm{d}$ of RPC had a more persistent $(\mathrm{P}<0.05)$ at early-lactation, higher milk yield, lowest health problems and no negative energy balance was observed compared to control group. Which agree with the results of the present study. Similar results which agree with results of this study were also reported by Elek (2008) and Soltan et al. (2012) who indicated that dietary RPM and/or choline additive, improved milk yield of dairy cows. Mohsen et al, (2011) reported that lactating cows fed ration supplemented with 15 or $30 \mathrm{~g} / \mathrm{head} /$ day of RPC recorded increase $(\mathrm{P}<0.05)$ in actual milk yield by 1.32 and $2.24 \mathrm{~kg} /$ head/day for 15 and $30 \mathrm{~g} \mathrm{RPC}$ compared with un-supplemented RPC, respectively. Zahra et al. (2006) reported that Holstein cows that received $56 \mathrm{~g}$ /day of RPC produced on average 1.2 $\mathrm{kg}$ /day more milk yield through 60 days compared with animals that did not receive any supplements. Erdman and Sharma (1991) found that addition of choline to rations of Holstein cows at levels of 0 , $0.078,0.156$, and $0.234 \% \mathrm{RPC}$ resulted in a linear increase in $3.5 \% \mathrm{FCM}$, and feeding 0.156 and $0.234 \%$ choline increased FCM by 2.4 and 1.7 $\mathrm{kg}$ /day, respectively, over the control group, these results are in agreement with our results . Guretzky et al. (2006) reported that feeding Holstein and Jersey cows' diets supplemented with $60 \mathrm{~g}$ RPC product resulted in increasing daily milk yield of $3.5 \%$ FCM by $2 \mathrm{~kg} / \mathrm{day}$, compared with the control group, which partially agree with the results of this study.

Jayaprakash et al. (2016) reported that supplementation of RPC increases the milk production as a result of higher digestibility and increased total VFA concentration, decreased $\mathrm{NH}_{3}-\mathrm{N}$, and prevention of metabolic disorders such as ketosis and fatty liver syndrome. On contrary to findings in this study, Leiva et al. (2015) reported that no treatment effects for cows supplemented with RPC were detected ( $\mathrm{P} \geq 0.43$ ) for milk yield parameters, such as fat-corrected or solids-corrected milk

Table 4. Average daily feed intake, milk yield and feed efficiency

\begin{tabular}{|c|c|c|c|c|}
\hline \multirow[t]{2}{*}{ Items } & \multicolumn{4}{|c|}{ Experimental rations } \\
\hline & R1 & R2 & R3 & $\pm \mathbf{S E}$ \\
\hline \multicolumn{5}{|c|}{ Average daily feed intake $\mathrm{kg}$ (as fed) $\mathrm{kg} / \mathrm{h} / \mathrm{d}$} \\
\hline Concentrate feed mixture & 12 & 12 & 12 & \\
\hline Clover hay & 3 & 3 & 3 & \\
\hline Rice straw & 4 & 4 & 4 & \\
\hline \multicolumn{5}{|c|}{ Average daily feed intake (on DM basis) $\mathrm{kg} / \mathrm{h} / \mathrm{d}$} \\
\hline Total DMI & 17.53 & 17.53 & 17.53 & \\
\hline TDN & 12.36 & 13.03 & 13.10 & 0.25 \\
\hline $\mathrm{DCP}$ & $1.91^{\mathrm{b}}$ & $2.19^{\mathrm{a}}$ & $2.17^{\mathrm{a}}$ & 0.06 \\
\hline \multicolumn{5}{|l|}{ Milk yield (kg/ h/d) } \\
\hline Actual daily milk yield & $16.93^{\mathrm{b}}$ & $18.86^{\mathrm{ab}}$ & $20.76^{\mathrm{a}}$ & 0.63 \\
\hline $4 \%$ fat corrected milk & 15.71 & $17.42^{\mathrm{b}}$ & $19.08^{\mathrm{a}}$ & 0.52 \\
\hline \multicolumn{5}{|l|}{ Feed conversion } \\
\hline $\mathrm{DM} \mathrm{kg} / \mathrm{kg} \mathrm{4 \%} \mathrm{FCM}$ & $1.12^{\mathrm{a}}$ & $1.01^{\mathrm{b}}$ & $0.92^{\mathrm{c}}$ & 0.02 \\
\hline TDN kg / kg 4\% FCM & 0.787 & 0.748 & 0.687 & 0.03 \\
\hline DCP g / kg 4\% FCM & 0.122 & 0.126 & 0.114 & 0.01 \\
\hline
\end{tabular}

$\mathrm{a}, \mathrm{b}, \mathrm{c}$ means on the same row with different super script are significantly $(\mathrm{p}<0.05)$ different.

\section{Feed efficiency:}

As shown in (Table 4) results of DCP intake were $(\mathrm{P}<0.05)$ significantly higher in favor of groups that were supplemented withRPC, compared with the control animals.

Regarding feed conversion ratio (FCR) in terms of the amount of DM, TDN and DCP used for producing one $\mathrm{Kg}$ actual or fat corrected milk (4\%), the 50 and $40 \mathrm{gm}$ RPC supplemented groups recorded significant differences $(\mathrm{P}<0.05)$. These positive results of FCR in favor of the groups supplemented with RPC could be attributed to the increase in TDN and DCP digestibility values as affected with RPC supplementation as given in Table 3. Piepenbrink and Overton (2003) and Guretzky et al. (2006), reported that RPC supplementation for cows did not affect DMI either pre-partum or during the first 3 weeks postpartum. This resultdisagrees with the results found in the present study. On the other hand, Mohsen et al. (2011) reported that RPC supplementation decreased the quantities of DM, TDN and DCP per kg 4\% FCM $(\mathrm{P}<0.05)$, which is in agreement with the results reported here in.

\section{Changes in Body Weight:}

As illustrated in Table 5 analyses of variance showed insignificant $(\mathrm{P}>0.05)$ differences among groups fed rations supplemented with 40 or 50 gm./cow /day RPC and the control in the change of live body weight at 15,30, 45 and 60 days postnatal. The recorded values in the change of live body weight were found to be (-) 2.15, (-) 4.51and (-) $7.53 \%$; (- ) 1.76, (-) 3.87 and (-) 5.28; (-) 1.53, (-) 
0.95 and $(+) 1.15 \%$ from the initial body weight at 30,45 and 60 days postnatal for the control compared with group fed 40 or 50 gm. RPC, respectively.

It should be noted that groups fed ration supplemented with RPC showed lower negative body change during $15,30,45$ and 60 days of lactation period compared with the control. Furthermore, group fed $50 \mathrm{gm}$ RPC recorded (+) increase in the body weight during last period (60 days) postnatal compared with other groups. This low negative as well as positive change in body weight in groups fed RPC could be attributed to the effect of RPC in improving the efficiency of utilizing either energy of the feed, or more efficient mobilization of stored fat

Table 5. Change in body weight

\begin{tabular}{lrrrrr}
\hline \multirow{2}{*}{ Item } & \multicolumn{3}{c}{ Experimental rations } & \multirow{2}{*}{ \pm SE } \\
\cline { 2 - 5 } & $\mathbf{R}_{\mathbf{1}}$ & $\mathbf{R}_{\mathbf{2}}$ & \multicolumn{2}{c}{$\mathbf{R}_{\mathbf{3}}$} \\
\hline Change in Live body weightWeighing time (days): & & & & \\
15 & 495.67 & 473.33 & 523.33 & 30.98 \\
30 & 485.00 & 465.00 & 515.33 & 33.56 \\
45 & 473.33 & 455.00 & 518.33 & 28.17 \\
60 & 458.33 & 448.33 & 529.33 & 29.24 \\
\hline
\end{tabular}

a,b,c means on the same row with different super script are significantly $(\mathrm{p}<0.05)$ different.

\section{Milk composition:}

As shown in (Table 6) results showed insignificant $(\mathrm{P}>0.05)$ differences among groups that were supplemented with RPC and the control in the content of milk protein, fat, SNF, TS and lactose. However, it could be noticed that RPC groups had higher milk protein and fat contents, while lactose content decreased with increasing level of RPC supplement compared with the control. Results of ash and moisture showed that group fed RPC had $(\mathrm{P}<0.05)$ higher ash content than the control. These results are in agreement with results reported by Ardalan et al. (2010). El-Gendy et al. (2012) reported that RPC was more effective in increasing the contents of fat, lactose, SNF, TS and ash in milk than the control. Also, Elek (2008) stated that milk yield, fat and protein contents in milk of cows were significantly higher with supplementation of RPC compared with the control. Soltan et al,. (2012) indicated that dietary RPM and/or RPC improved energy in the body in the groups fed RPC, resulting in faster recovery than the control group.

Soltan et al. (2012) found that cows fed on basal diet supplemented with both RPM and RPC were mobilizing less body tissue in the post-partum period. In early lactation on dairy animals, the majority of fatty acids secreted by mammary gland could lead to increase animal weight loss, increased incidence of fatty liver, and increasing the chance of sub-clinical and clinical ketosis that agreed with the results obtained in this current study (Bindel et al. (2000), Pinotti el al. (2003), Cooke et al. (2007), Zom et al., (2011), Rahamani et al. (2014), and Jayaprakash et al. (2016)).

Table 6. Milk composition of the experimental groups

\begin{tabular}{ccccc}
\hline \multirow{2}{*}{ Item } & \multicolumn{3}{c}{ Experimental rations } & \multirow{2}{*}{ \pm SE } \\
\cline { 2 - 4 } & $\mathbf{R}_{\mathbf{1}}$ & $\mathbf{R}_{\mathbf{2}}$ & $\mathbf{R}_{\mathbf{3}}$ & \\
\hline Protein & 2.58 & 2.74 & 2.64 & 0.09 \\
Fat & 3.46 & 3.49 & 3.52 & 0.05 \\
SNF & 8.01 & 7.47 & 7.65 & 0.24 \\
TS & 11.47 & 10.96 & 11.17 & 0.23 \\
Lactose & 4.95 & 4.31 & 4.50 & 0.19 \\
Ash & $0.48^{\mathrm{ab}}$ & $0.42^{\mathrm{b}}$ & $0.51^{\mathrm{a}}$ & 0.02 \\
Moisture & 88.53 & 89.04 & 88.83 & 0.21 \\
\hline
\end{tabular}

a,b,c means on the same row with different super script are significantly $(\mathrm{p}<0.05)$ different

\section{Blood constituents:}

Results of blood analyses are shown in Table 7. Statistical analyses for AST, ALT and cholesterol milk yield and composition of dairy cows. Similar results were reported by Mohsen et al. (2011) who found that the contents of fat and TS, and the yield of all milk constituents, except ash, significantly $(\mathrm{P}<0.05)$ increased with RPC supplementation.

The aforementioned results of the current study on milk composition were found to be in agreement with those reported by Sharma and Erdman, (1988); Erdman and Sharma, (1991); Zahra et al. (2006) and Ambrosio et al. (2007). Jayaprakash et al. (2016) reported that during the transition period, RPC supplemented cows changed plasma NEFA concentration, and increased hepatic fat export, and this may result in decreasing the risk for metabolic disorders and increase in milk and change in milk composition. On the contrary, Leiva et al. (2015) reported that cows supplemented with RPC had greater $(\mathrm{P}<0.01)$ milk protein, $\mathrm{TS}(\mathrm{P}<0.01)$, and milk fat concentrations $(\mathrm{P}=0.09)$ compared with control.

contents of the blood showed no significant $(\mathrm{P}>0.05)$ differences between RPC groups and the control, while RPC supplementation groups recorded 
$(\mathrm{P}<0.05)$ low values of triglycerides and $\mathrm{LDL}$ compared with the control. On the other hand, RPC recorded significantly $(\mathrm{P}<0.05)$ higher values of HDL compared with the control. However, all recorded values of blood constituents for the three tested groups were found to be within the normal range.Zom et al (2011) reported that choline supplementation decreased the concentration of liver triacylglycerol during the first 4 weeks after parturition. Cooke et al (2007) implied that RPC could prevent, and possibly alleviate development of fatty liver because of increased rate of triacylglycerol depletion from the liver, at least when induced by feed restriction. Piepenbrink and Overton (2003) suggested that feeding RPC to transition cows increased the rate of VLDL secretion by the liver.Cooke et al (2007), reported that feeding RPC $(15 \mathrm{~g} / \mathrm{d})$ decreased liver triglyceride accumulation during induction of fatty liver through feed restriction. It also enhanced triglyceride depletion from liver. Mohsen et al (2011) reported that RPC supplementation in dairy cow led to a significant decrease $(\mathrm{P}<0.05)$ in the concentrations of plasma cholesterol and triglycerides, while AST and ALT were insignificant affected.

Table 7. Blood constituents of the experimental groups

\begin{tabular}{ccccc}
\hline \multirow{2}{*}{ Item } & \multicolumn{3}{c}{ Experimental rations } & \multirow{2}{*}{ \pm SE } \\
\cline { 2 - 4 } & $\mathbf{R}_{\mathbf{1}}$ & $\mathbf{R}_{\mathbf{2}}$ & $\mathbf{R}_{\mathbf{3}}$ & \\
\hline AST & 66.00 & 65.417 & 64.58 & 0.93 \\
ALT & 18.33 & 18.833 & 20.92 & 6.21 \\
Cholesterol & 102.58 & 108.50 & 102.58 & 0.67 \\
Triglycerides & $22.67^{\mathrm{b}}$ & $25.75^{\mathrm{a}}$ & $14.41^{\mathrm{c}}$ & 0.93 \\
HDL & $19.08^{\mathrm{b}}$ & $23.00^{\mathrm{a}}$ & $22.75^{\mathrm{a}}$ & 4.86 \\
LDL & $74.78^{\mathrm{a}}$ & $72.80^{\mathrm{a}}$ & $53.72^{\mathrm{b}}$ & 4 \\
\hline
\end{tabular}

a,b,c means on the same row with different super script are significantly $(\mathrm{p}<0.05)$ different.

\section{Economic efficiency:}

Results in Table 8 show that RPC 50 and $40 \mathrm{gm}$ supplementation resulted in a linear decrease in the cost of the feed used for producing one $\mathrm{Kg}$ of $4 \%$ FCM, being $3.77,3.47$ and $3.17 \mathrm{LE}$, and linear increase in the net revenue of daily milk yield, being 47.76 and 58.76 compared to $37.78 \mathrm{LE}$ for the control. Results also revealed that supplementation with RPC at 40 and $50 \mathrm{gm}$ achieved the highest relative economic efficiency (126.4 and $156 \%$ ) compared with the control $(100 \%)$. These positive results of economic efficiency as a result of RPC supplementation could be attributed to the improvement in the digestibility and productive performance of dairy cow in the current study. The obtained economical evaluation results are found to be very close to those reported earlier by Mohsen et al (2011) who found that average daily feed cost per $\mathrm{kg} 4 \%$ FCM was decreased significantly $(\mathrm{P}<0.05)$ with increasing level of RPC by $5.20 \mathrm{LE}$, and net revenues were increased by 2.92 and $4.88 \mathrm{LE}$ for 15 and $30 \mathrm{~g}$ RPC supplementation, respectively, compared with the un-supplemented treatment.

Table 8. Effect of experimental rations on economic efficiency

\begin{tabular}{lccc}
\hline Items & \multicolumn{3}{c}{ Experimental rations } \\
\cline { 2 - 4 } & $\mathbf{R}_{\mathbf{1}}$ & $\mathbf{R}_{\mathbf{2}}$ & $\mathbf{R}_{\mathbf{3}}$ \\
\hline Actual daily milk yield & 16.93 & 18.86 & 20.76 \\
Fat corrected milk (4\%) & 15.71 & 17.42 & 19.08 \\
Total DMI & 17.53 & 17.53 & 17.53 \\
Daily feed cost (LE) & 63.8 & 65.4 & 65.8 \\
Feed cost (LE)/ kgmilk & 3.77 & 3.47 & 3.17 \\
Av. Revenue daily of milk yield (LE) & 101.58 & 113.16 & 124.56 \\
Net feed revenue (LE) & 37.78 & 47.76 & 58.76 \\
Economic feed efficiency \% & $59.2 \%$ & $73.0 \%$ & $89.3 \%$ \\
Relative Economic efficiency \% & 100 & $126.4 \%$ & $156 \%$ \\
\hline
\end{tabular}

market price at the time of experimentation for 1 ton CFM were 4500 LE., 1 ton Egyptian clover hay= 2000 LE, 1 ton rice straw $=600 \mathrm{~L} . \mathrm{E}, 40 \mathrm{LE}$ per $1 \mathrm{Kg}$ protected choline and $6 \mathrm{LE} / \mathrm{Kg}$ of milk.

\section{CONCLUSION}

The results obtained in the present study, support the conclusion that rumen-protected choline (RPCsupplementation, at $40 \mathrm{~g}$ or 50 /head/day to lactating cows, improved nutrient digestibility, milk yield and composition, feed conversion and economic efficiency. The supplementation of $50 \mathrm{gr} / \mathrm{head} /$ day had better effect on economic evaluation and animal performance than 40 gr supplementation.
The authors suggested that more studies are needed with high number of dairy animal.

\section{ACKNOWLEDGEMENT}

The research team of this current study acknowledges and highly appreciates the help offered by DPA SERVICE company in Egypt, the official distributor of the Brand Choline -Save ${ }^{\circledR}$ product of PACTA- Italy 


\section{REFERENCIES}

Ambrosio, F.D., A. Campagnoli, F. Susca, E. Fusi, R. Rebucci, A. Agazzi, 1. Pinotti, A. Baldi., 2007. Effects of rumen-protectedcholine supplementation in periparturient dairy goats.Vet. Res. Commun., vol. 31(Suppl. 1): 393-396.

Ardalan, M.M.,dehghan-banadaky and Kamran rezayazdi, 2010. Milk yield persistency and its relationship with health problems in Holstein dairy cows supplemented with different levels of ruminally protected methionine and choline. ArchivTierzucht 53 (2010) 3, 266-276, ISSN 0003-9438C Leibniz Institute for Farm Animal Biology, Dummerstorf, Germany

Atkins, K.B., R.A. Erdman and J.H. Vandersall, 1988. Dietary choline effects on milk yield and duodenal flow in dairy cattle, J. Dairy Sci., vol. 71(1): 109-116.

A.O.A.C., 1995. Official Methods of Analysis $\left(16^{\text {th }}\right.$ Ed.).Association of Official Analytical Chemists, Washington, D.C., USA.

BindelD. J,J.S. Drouillard, E.C. Titgemeyer, R.H. Wessels and C.A. Loest, 2000. Effects of ruminally protected choline and dietary fat on performance and blood metabolites of finishing heifers. J Anim Sci., 78(10):2497-2503.

Bobe, G.,J.W. Young and D.C. Beitz, 2004. Invited review: Pathology, etiology, prevention, and treatment of fatty liver in dairy cows. J. Dairy Sci. 87:3105-3124.

Cole, L.K.,J.E. Vance and D.E. Vance, 2011.Phosphatidylcholine biosynthesis and lipoprotein metabolism. Biochim. Biophys. Acta. 1821:754-761.

Cooke, R.F., N. Silva,D.Z. Del Rio, S.J. Caraviello,M.H. Bertics and R.R. Grummer, 2007. Supplemental choline for prevention and alleviation of fatty liver in dairy cattle. J. Dairy Sci. 90: 2413-2418.

Deuchler, K.N.,L.S. Piperova and R.A. Erdman, 1998. Milk choline secretion as an indirect indicator of post ruminal choline supply. J. Dairy Sci. 81:238-242.

Donkin, S.S., 2002. Rumen-protected choline: potential for improving health and production in dairy cows. Tri-State Nutrition Conference, Ft. Wayne, IN, pp. 55.

Duncan, D.B., 1955. Multiple Range and Multiple F Test. Biometrics, 11:10.

Elek P., 2008. Decrease of losses due to disorders in lipid metabolism of high producing dairy cows by feeding of rumen protected choline. Ph.D. Thesis,University of Pannonia, Keszthely, Hungary.

El-Gendy, M.E, Kotob F. El-Riedy, Hanaa S. Sakr, Hamed M. Gaafar, 2012. Effect of Rumen Protected Methionine and/or Choline Additives on Productive Performance of Zaraibi Goats .Nature and Science 2012,10.

Erdman R.A., R.D. Shave and J.H. Vandersall, 1984. Dietary choline for the lactating cow: Possible effects onmilk fat synthesis. J. Dairy Sci. 67: 410-415.

Erdman, R.A. and B.K. Sharma, 1991. Effect of dietary rumen protected choline in lactating dairycows. J. Dairy Sci., vol. 74: 1641-1647.

Gaine, W.L.,1928. An efficiency formula for dairy cows. J. Animal science: 67: 353.

Gornall, A.G.,C.J. Bardawill and M.M. David, 1949. Determination of serum proteins by means of the biuret reaction. J. Biol. Chem., 177:751-759.

Grummer, R. R., 1993. Etiology of lipid related metabolic disorders in periparturient dairy cattle. J. Dairy Sci. 76:3882-3896.

Guretzky, N., A. Janovick, D. B. Carlson, J. E. garrett and J. K. drackley, 2006. Lipid metabolite profiles and milk production for Holstein and Jersey cows fed rumen-protected choline during the periparturient period. $J$. Dairy Sci., vol. 89:188- 200.

Hartwell, J.R.,M.J. Cecava and S.S. Donkin, 2000. Impact of dietary undegradable protein and rumen-protected choline on intake, per partum liver triacyl glycerides, plasma metabolites and milk production in transition dairy cows. J. Dairy Sci. 83:2907-2917.

Jayaprakash, G.,M. Sathiyabarathi,M. Arokia Robert and T. Tamilmani , 2016.Rumenprotected choline: A significance effect on dairy cattle nutrition. Vet world 2016 Aug, 9(8): 837841.

Leiva, T.,R.F. Cooke, A.P. Brandão, R.S. Marques and J.L. Vasconcelos, 2015. Effects of rumenprotected choline supplementation on metabolic and performance responses of transition dairy cows.J animal scince,93(4):1896-904.

Lima, F.S.,M.F. SaFilho, L. F. Creco and J. E. P. Santos, 2011. Effects of feeding rumenprotected choline on incidence of diseases and reproduction in dairy cows. Vet. J. (in press/available on line).

Mohsen, M.K.,H.M.A. Gaafar, M.M. Khalafalla,A.A. Shitta and A.M. Yousif, 2011. Effect of rumen protectedcholine supplementation on digestibility, rumenactivity and milk yield in lactating Friesian cows.Slovak J. Anim. Sci. 44(1): 13-20.

NRC (2001). Nutrient requirements of dairy cattle. $\left(7^{\text {th }}\right.$ Rev. Ed.).National Academy Press, Washington, DC,Page 169.

Pinotti, L., A. Baldi and V. Dell'Orto, 2002.Comparative mammalian choline metabolism with emphasis on the high-yielding dairy cow. Nutr. Res. Rev. 15:315-332. 
Pinotti, L., A. Baldi, I. Politis, R. Rebucci, L. Sangalli and V. Dell'Orto, 2003. Rumenprotected choline administration totransition cows: Effects on milk production and vitamin $\mathrm{E}$ status. Vet Med. Ser. A 50:18-21.

Piepenbrink, M.S., and T.R. Overton., 2003. Liver metabolism and production of cows fed increasing amounts of rumen-protected choline during the pre parturient period. J. Dairy Sci. 86: 1722-1733.

Rahamani M., M. Dehghan-Banadaky and R. Kamalyan, 2014. Effects of feeding rumen protected choline and Vitamin E on milk yield, milk composition, dry matter intake, body condition score and body weight in early lactating dairy cows. Iran. J Appl. Anim. Sci. 4(4):693-698.

Reitman, S. and S. Frankel, 1975. Colorimetric determination of GPt activity according to the Reitman and Frankel method. Am. J. Clin. Path., 28-56.

Reynolds, C. K., P. C. Aikman, B. Lupoli, D. J. Humphries and D. E. Beaver, 2003. Splanchnic metabolism of dairy cows during the transition from late gestation through early lactation. J. Dairy Sci. 86:1201-1217.

SAS.,2003. SAS Procedure Users Guide "version 6.12 Ed”.SAS Institute Inc., Cary, NC, USA.

Sharma, B.K. and R.A. Erdman, 1988. Effect of high amounts of dietary choline supplementation on duodenal choline flow and production responses of dairy cows. J Dairy Sci $71,2670-6$.
Schnider, B. H. and W. P. Flatt, 1975. The Evaluation of feeds through digestibility experiments. The University of Georgia press, Athens, USA: 423.

Soltan M. A., A. M. Mujalli, M.A. Mandour and M. El- ShinwayAbeer, 2012. Effect of dietary rumen protected methionine and/or choline supplementation on rumen fermentation characteristics and productive performance of early lactating Cows. Pakistan Journal of Nutrition, 11(3): 221-230

Van Keulen, I. and B. A.Young, 1977. Evaluation of acid insoluble ash as a natural marker in ruminant digestibility studies. J. Anim. Sci., 44 (2): 282-287.

Xu, G.,J. Ye, J. Liu and Y. Yu., 2006. Effect of rumen-protected choline addition on milk performance and blood metabolic parameters in transition dairy cows. Asian-Aust. J. Anim. Sci. 19:390-395.

Zahra, L. C., T. F. Duffiled, K. E. Leslie, T. R. Overton, D. Putnam and S. J. LeBlanc., 2006. Effects of rumen-protected choline and monensin on milk production and metabolism of pre parturient cows. J. Dairy Sci. 89:48084818.

Zom, R. L. G, J. van Baal, R. M. A. Goselink, J. A. Bakker, M. J. de Veth and A. M. van Vuuren, 2011. Effect of rumen-protected choline on performance, blood metabolites, and hepatic triacylglycerols of periparturient dairy cattle. J. Dairy Sci. 94:4016-4027.

\footnotetext{
تأثير إضافة الكولين المحمي على الاداء الانتاجى للابقار الحلابة محمد حسن بكر' ، شيرين حمدى محمد' ا- قسم الاتتاج الحيوانى، كلية الزراعة، جامعة القاهرة، بـ قسم الانتاج الحيوانى، كلية الزراعة، بمشتهز جامعة بنها

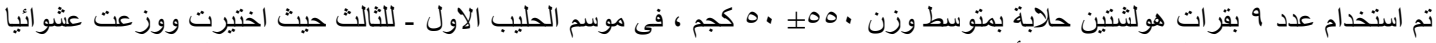

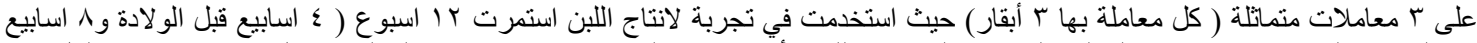

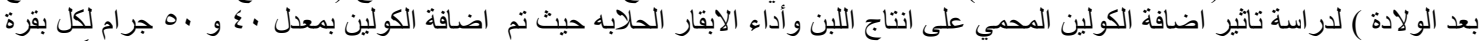

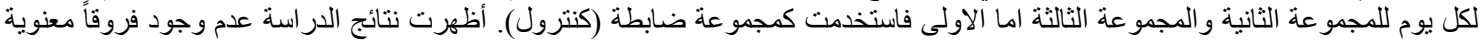

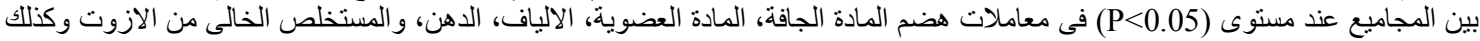

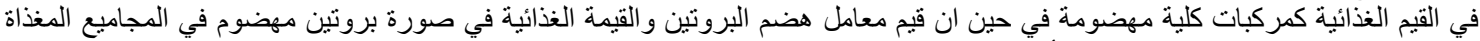

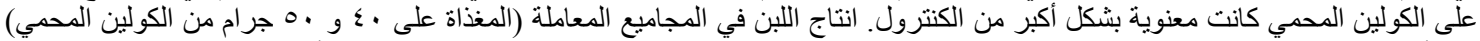

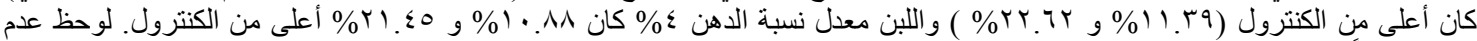

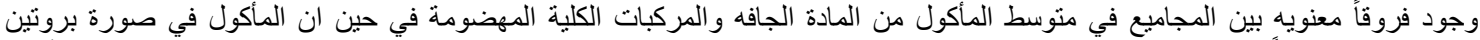

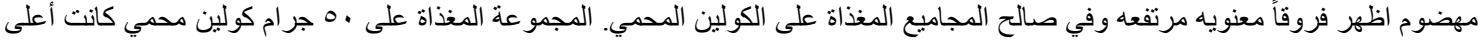

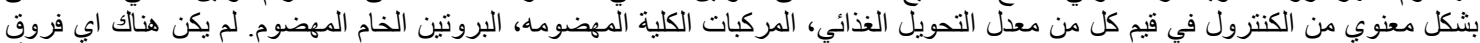

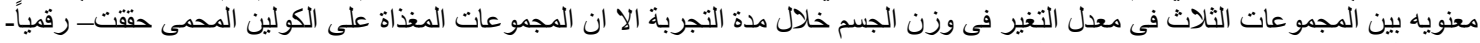

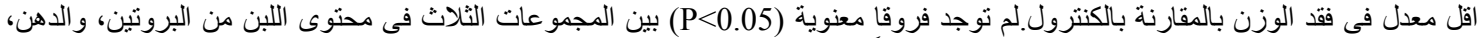

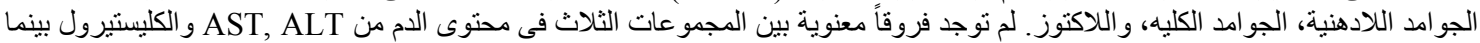

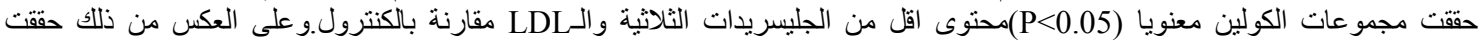

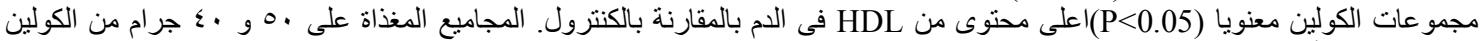

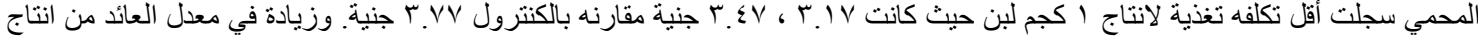

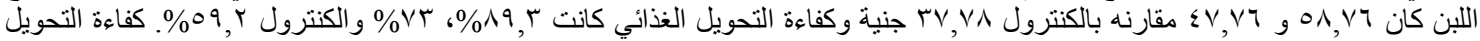

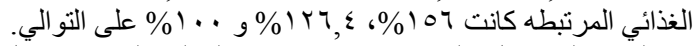

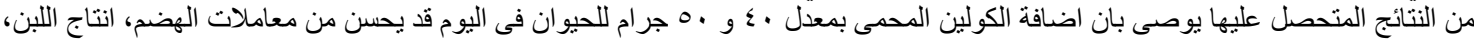
تركيبه، والكفاءة الاقتصادية في الابقار الهولثتين الحلابه. مطلوب العديد من الابحاث في هذا المجال مع استخدام عدد اكبر من الحيو انات الحلابه.
} 